\title{
CASE STUDY \\ Hurricane Katrina and Oil Spills: Impact on Coastal and Ocean Environments
}

\author{
BY JOHN C. PINE
}

Hurricane Katrina, the third major hurricane of the 2005 Atlantic Hurricane Season, made landfall in Buras, Louisiana at 6:10 AM CDT on August $29^{\text {th }}$ as a Category 4 storm. The estimated death toll from Katrina of 1242 makes it the deadliest storm to hit the United States in over 75 years. The direct financial costs in property losses from Hurricane Katrina are estimated to exceed $\$ 200$ billion.

Katrina's sustained winds of $140 \mathrm{mph}$ (225 kph) had a dramatic impact on Plaquemine Parish, making landfall just south of Buras, LA. Katrina continued northward and made its second landfall near the Louisiana/Mississippi border at 10:00 AM CDT with estimated maximum sustained winds of near $125 \mathrm{mph}$ (201 kph), making it a Category 3 storm (National Weather Service [NWS], 2005). The NWS stated that, at the eye of the storm in far southeast Louisiana, wind gusts were as high as $155 \mathrm{mph}$ (249 kph). In Waveland and Bay St. Louis, Mississippi, a storm tide of 30 feet (9 meters) above mean sea level (MSL) was measured, Katrina's highest. A height of 14 feet (4.3 meters) above MSL was recorded in St. Bernard Parish (Marshall). As a result of the high winds and the storm surge, the southeastern parishes in Louisiana (Plaquemines, St. Bernard, Orleans, and St. Tammany) and the coastal counties in Mississippi suffered the greatest property losses from this storm.

The National Oceanic and Atmospheric Administration (NOAA) assessed ground and aerial damage immediately after landfall. The storm's tide and wind resulted in catastrophic destruction of hurricane-protection levees, bridges, roads, homes, businesses, industrial facilities, and pipelines. In a September 9, 2005, response agencies, including NOAA's Office of Response and Restoration, the U.S. Coast
Guard, the Environmental Protection Agency (EPA), and the State of Louisiana Department of Environmental Quality, had been notified of more than $\mathbf{2 0 0}$ hazardous materials releases and additional hazardous material problems (e.g., hundreds of stranded drums of unknown materials; see Box 1). In addition, NOAA had been notified of more than 70 salvage operations that had some type of pollution threat.

In addition to the coastal and waterway response operation by NOAA and other federal and state partners, the Minerals Management Service (MMS) within the U.S. Department of the Interior, which manages offshore oil and gas operations, has been key in evaluating the damage wrought by the two major 2005 hurricanes (Katrina and Rita). The MMS estimated that one-third of the Gulf of Mexico's
4,000 platforms and two-thirds of the Gulf's pipelines had been in the direct path of either Hurricane Katrina or Hurricane Rita. These storms destroyed 46 platforms and damaged 20 others. To date, 100 damaged pipelines and 211 minor pollution incidents involving less than 500 barrels of oil have been reported to MMS (Minerals Management Service, 2005).

Nearly 50 oil spills were reported in the nearshore environment (Figure 1), including spills from Meraux, LA (Murphy Oil Corporation) in the metropolitan area of New Orleans, as well as coastal areas at the mouth of the Mississippi River at Empire (Chevron Oil), Pilot Town (Shell Oil), and Cox Bay (Bass Enterprises Production Company). Figure 2 shows the location of the spills in the southern Louisiana coastal areas. Many of the spills were from facilities, which

\section{BOX 1. CHEMICAL RELEASES FROM HURRICANE KATRINA IN THE LOWER MISSISSIPPI CORRIDOR}

Bass Enterprises Production Company (Cox Bay): 3.78 million gallons discharged.

Shell (Pilot Town): 1.05 million gallons discharged.

Chevron (Empire): 991,000 gallons discharged.

Murphy Oil Corporation (Meraux): 819,000 gallons discharged.

Bass Enterprises (Point a la Hache): 461,000 gallons of oil discharged.

Chevron (Port Fourchon): About 53,000 gallons discharged.

Venice Energy Services Company (Venice): 840,000 gallons discharged.

Shell Pipeline Oil (Nairn): 13,440 gallons discharged.

Sundown Energy (West Potash): 13,000 gallons discharged. 
Figure 1. Breton Sound oil slick seen from a helicopter after Hurricane Katrina struck the Gulf Coast. Photo provided by NOAA (available at http://www.noaanews. noaa.gov/stories2005/s2517.htm).

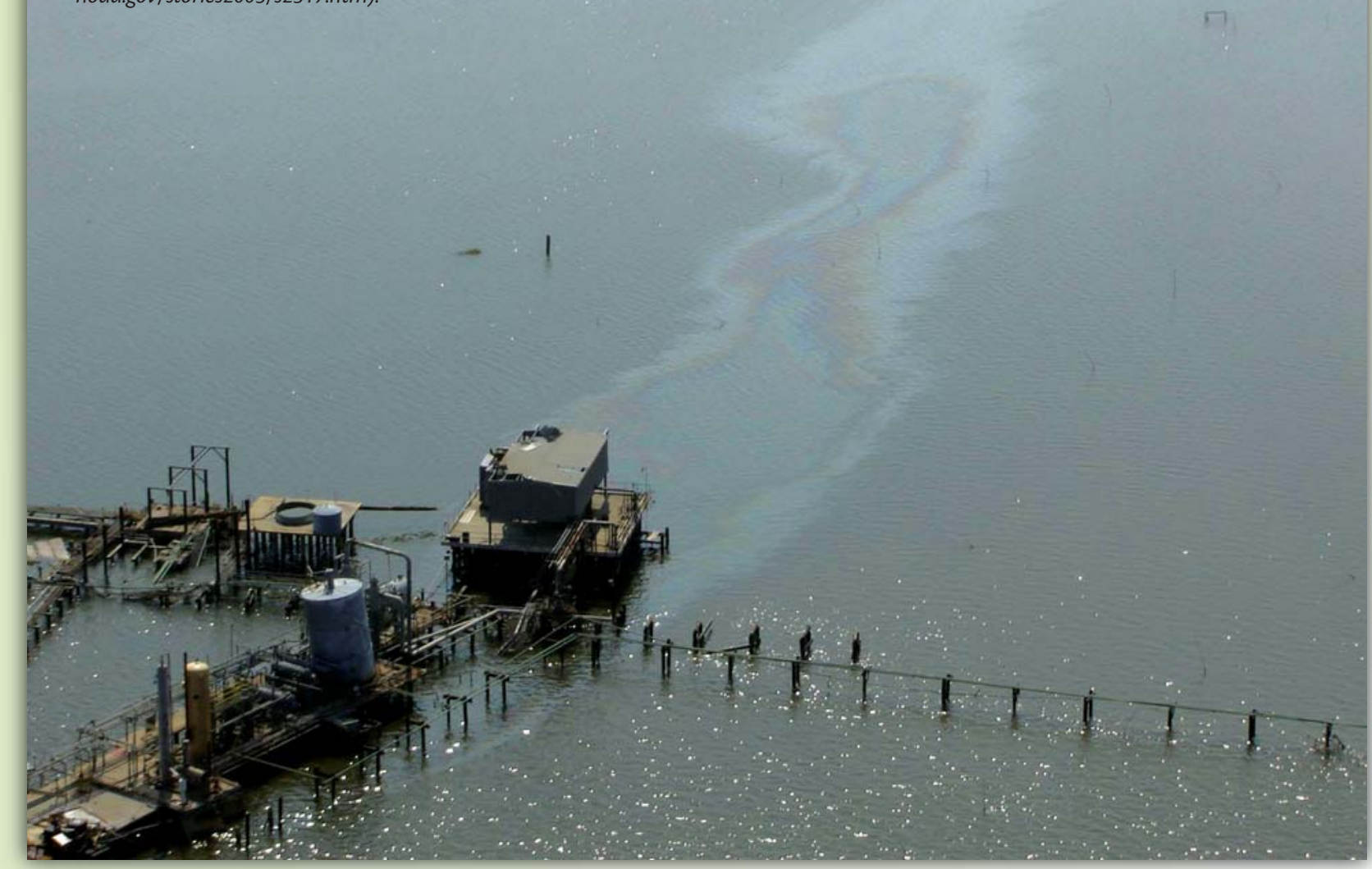

affected the immediate area around the sites. Other spills resulted from breaches in pipelines, affecting coastal marshes.

The Murphy Oil spill was the largest release, with approximately 819,000 gallons $(3,100,243$ liters) spilling into a highly populated area of St. Bernard Parish. The spill occurred when an above-ground storage tank was dislodged, lifted, and damaged as a result of storm surge and flooding associated with Hurricane Katrina. Approximately 305,000 gallons $(1,154,547$ liters) were recovered, 196,000 gallons ( 741,938 liters) were contained, 312,000 gallons (1,181,045 liters) evaporated, and 6,000 gallons (22,712 liters) were not recovered. The released oil had an impact on approximately 1700 homes in an adjacent residential neighborhood (an area of about one square mile or 2.6 square kilometers). Local area canals had also been impacted (more information available at http://www. epa.gov/katrina/waterissues.html). Although the Shell Oil Company spill was much smaller (13,400 gallons [ 50,724 liters]), 10,500 gallons (39,747 liters) of this spill reached the shoreline and the coastal marshes. The crude oil in this spill leaked from a 20 -inch $(50.8-\mathrm{cm})$ pipeline that was damaged as a result of a breach in the hurricane-protection levee. This spill mainly affected the coastal marsh found outside the levee. In addition to the oil spills from facilities and pipelines, responders had to deal with sunken or grounded vessels that were carrying petroleum products.

Although all the releases were caused by Hurricane Katrina, the cleanup and recovery options have been drastically different for each event. Cleanup strategies in the residential areas were very different than those in marsh areas. The transportation and movement of cleanup crews and materials in the urban areas around Murphy Oil Company dealt with reduced accessibility due to the downed power lines and flooded roads. Other spills primarily affected the coastal marshes; cleanup crews had access to those sites through the use of boats and barges. Coastal cleanup methods included use of in situ burn techniques, which involved fewer response resources and had proven to be one of the best environmental removal methods for reducing impacts to the sensitive coastal marsh.

The short-term and long-term impacts of these oil releases on ecosystems along the many 


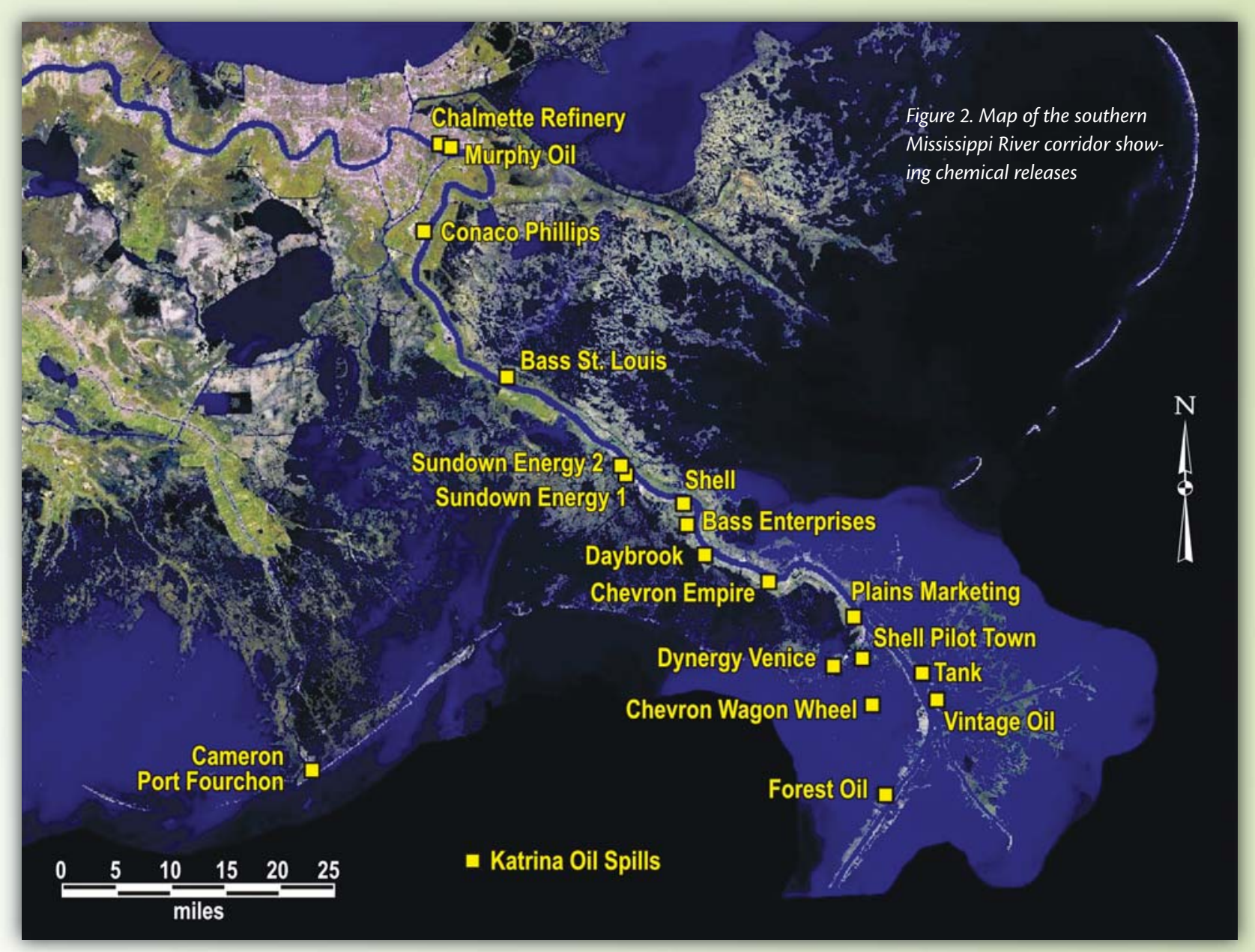

miles of coastline have been and will continue to be examined by the teams from NOAAs Office of Response and Restoration (Hogarth, 2005). They will be monitoring the impacted coastal areas for at least a year following Hurricane Katrina. Agency teams will monitor shallow nearshore and wetland environments in areas impacted by chemical releases in an effort to characterize the magnitude and extent of coastal contamination and ecological effects resulting from this storm. The types of assessments include ongoing examination of coastal ecosystems, biological condition, fisheries, water quality, sediment quality, seafood safety, and human-health risks in coastal ecosystems of Louisiana, Mississippi, and Alabama.

Alabama, Louisiana, and Mississippi state agencies as well as federal agencies, includ- ing the U.S. Food and Drug Administration (FDA), EPA, and NOAA, have analyzed and will continue to monitor many samples of fish and shellfish from the waters affected by Hurricanes Katrina abd Rita. These agencies have reported that tests verify that there is no reason for concern about consuming seafood from the Gulf region due to the hurricanes.

Although many oyster harvest areas have been tested and re-opened, other areas remain closed until routine sampling by existing state regulated shellfish programs determine that oyster harvesting can resume.

\section{REFERENCES}

Hogarth, W. 2005. Testimony on the Effects of Hurricanes Katrina and Rita on the Fishing Industry and Fishing Communities in the Gulf of Mexico before the House Committee on Resources, Subcommit- tee on Fisheries and Oceans. December 15, 2005. [Online] Available at: http://www.ogc.doc.gov/ogc/ legreg/testimon/109f/hogarth1215.htm [last accessed April 5, 2006].

Minerals Management Service. 2005. Impact Assessment of Offshore Facilities from Hurricanes Katrina and Rita. U.S. Department of the Interior, Office of Public Affairs January 19, 2006. [Online] Available at: http://www.gomr.mms.gov/homepg/ whatsnew/newsreal/2006/060119.pdf [last accessed April 5, 2006].

National Weather Service. 2005. Post Storm Data Acquisition Aerial Wind Analysis and Damage Assessment Hurricane Katrina. [Online] Available at: http://www.nws.noaa.gov/os/data/pdfs/ KatrinaPSDA.pdf [last accessed April 5, 2006].

JOHN C. PINE (jpine@lsu.edu) is Interim Chair, Department of Geography and Anthropology and Director, Disaster Science and Management, Louisiana State University, Baton Rouge, LA, USA. 